\title{
FOREIGN DIRECT INVESTMENT IN CHINA: \\ BEYOND THE REPRESENTATIVE OFFICE
}

\author{
(Diego Quer and Enrique Claver)
}

\begin{abstract}
Nowadays, China is one of the most important destinations for international expansion of firms from all over the world. Based on the traditional theory on foreign direct investment and the resource-based view of the firm, this paper analyzes the influence of various firm- and industryspecific factors on the choice among three different modes of entry into China: representative office, joint venture, and wholly-owned subsidiary. The results suggest that firm size, firm performance as well as the investment in manufacturing facilities are positively related to entry modes that involve a high level of resource commitment. Restrictions to foreign investment in the industry affect these relationships.
\end{abstract}

\section{KEYWORDS}

FDI mode choice; China; firm-specific factors. 


\section{INTRODUCTION}

Choosing the most suitable entry mode is one of the most important strategic decisions that a firm must adopt during its internationalization process. In recent years, many research studies on this topic have focused on China, a country which is becoming a basic reference for the global environment where firms have to compete (Peng, Lu, Shenkar and Wang 2001). China offers a very important potential market, for out of its 1300 million inhabitants, approximately 80 million have a purchasing power similar to the average one in Western countries. In 1979 China started a progressive opening-up policy, leading to a thorough reform of its economic structures. Since then, one of China's main objectives has been to attract foreign capital, which has led it to progressively liberalize foreign investment and to attempt to create a suitable framework for such investment. The financial and technological boost coming from abroad has become a cornerstone of the country's economic development. In 2004, with a record entry of 60,630 million dollars, China was the world's third-largest recipient of foreign direct investment (FDI), behind the United States and the United Kingdom (UNCTAD 2005).

FDI in China may be carried out in various modes, the most frequent being the following. First, the representative office, which is usually the next stage after exports, allowing the development of a liaison structure and an increase of the trade activity. The representative office may engage in any of the following functions: conducting research and providing data and promotion materials to potential clients and partners; conducting research and surveying 
for its parent company in the local market; liaising with local and foreign contacts in China on behalf of it's parent company; acting as a coordinator for the parent company's activities in China; making travel arrangements for parent company representatives and potential Chinese clients; and other non-profit making business activities. Such offices are not allowed to execute agreements on behalf of the company they represent, and must operate through agents and distributors. However, in practice, the presence in China of foreign representatives has permitted many firms to establish real distribution channels which are supported by a single representative office. Many firms choose to set up a representative office in order to gain experience and a better understanding of the size and potential of the China market. Firms usually start with a low equity entry mode, such as a representative office, and when they accumulate experience they switch to a high equity mode, such as a joint ventures or wholly foreign owned enterprises.

There are two options for setting up a joint venture in China: equity joint venture, with limited liability on the equity, where the Chinese and the foreign party jointly manage the business, but the foreign share cannot be lower than 25 per cent; and cooperative or contractual joint venture, which is more flexible, for the partners may agree a share of the profits different from their share in the equity. This latter option is an interesting one in those cases where the foreign partner will contribute most of the financing, but its share is limited to a maximum percentage, as the sector is a restricted one.

The third mode of FDI is the wholly foreign owned enterprise, permitted as of 1986, only for projects which favour Chinese economy and fulfil at least one of the two following purposes: use of international advanced technology, or export of all or most of the products manufactured.

Given the characteristics of these three generic modes of entry into China, it may be considered that the foreign firm will choose a higher degree of commitment insofar as it moves from a 
representative office towards a joint venture, and from there towards a wholly-owned subsidiary.

In recent literature on international business we find various studies on the factors conditioning the degree of commitment for entry into China, although with different approaches: impact of experience and imitation on foreign subsidiary ownership (Guillén 2003); test of a hierarchical model on the factors influencing entry mode choice, between equity-based [joint venture or wholly-owned subsidiary] or non-equity-based [contract or exports] (Tse, Pan and Au 1997; Pan and Tse 2000); influence of four-level contingencies (nation, industry, firm, and project) on the choice between joint venture and wholly-owned subsidiary (Luo 2001); factors influencing the entry mode (contract, joint venture, or wholly-owned subsidiary) and their impact on performance (Chen and $\mathrm{Hu} 2002$ ); or factors determining the ownership share of the foreign partner in joint ventures established in China (Hu and Chen 1993; Pan 1996; Chadee 2002; Chen, $\mathrm{Hu}$ and $\mathrm{Hu} 2002)$.

A review of these contributions shows some issues that need further research. From a theoretical standpoint, these studies have focused on the most advanced FDI modes (joint venture or wholly-owned subsidiary), without considering representative offices, which often constitute an initial step prior to later, more committed investment. From an empirical point of view, the foreign firms discussed in these studies originate from more than one country, usually those with a greater presence in China (Hong Kong, USA, Japan, Korea, Singapore, Germany, or UK).

This paper would like to overcome these limitations by including representative offices as an initial step towards FDI, and considering a sample from a single country (Spain), whose FDI flows in China so far has been lower to that of the aforementioned countries (China FDI 2003). In addition, our paper is the first that focuses on the Spanish firms' choice among FDI modes in China. Regarding this issue, the only study carried out so far is that by Durán, Jun and 
Úbeda (1995) on Spanish firms attending the Spanish Expotecnia in Beijing in 1994, which might be potential investors in China. That study analyzed whether governmental support and specialized information conditioned the gradual nature of the internationalization process. Based on the traditional theory on FDI and the resource-based view of the firm (RBV), we would like to offer a contribution to the knowledge of the firm- and industry-specific factors that affect the investment strategy used to enter the Chinese market. In the following sections, we begin with the theoretical background and hypotheses. Methodological issues and results are then provided. Finally, we present the main conclusions, contributions and limitations of the study and suggest some lines for future research.

\section{LITERATURE REVIEW AND HYPOTHESES}

\section{Firm-specific factors}

One of the pioneering approaches explaining FDIs and, as a result, the existence of a multinational enterprise (MNE) is the Monopolistic Advantage Theory (Kindleberger 1969; Hymer 1976). Such conceptual framework, based on Industrial Organization Economics, argues that a foreign-owned firm must possess some specific advantages allowing it to compete on equal terms with local enterprises. According to this hypothesis, FDI occurs because the structural imperfections of the market (economies of scale, knowledge advantages or diversification) allow firms to obtain a monopolistic power in foreign markets.

Firm-specific factors are also one of the cornerstones of the Eclectic Paradigm of International Production (Dunning 1981, 1988). This model argues that the first condition for a firm to commit itself to FDI is its possessing an ownership advantage over firms from other nationalities. The Eclectic Paradigm also includes the internalization advantages (which 
determine whether the firm will organize its activity through the market or through internal means -hierarchy-) and location advantages (which influence the choice of the country). Dunning (1988) defined two categories of ownership advantages: assets advantages and transaction advantages of MNEs. While the former arise from the proprietary ownership of specific assets by MNEs vis-à-vis those possessed by other enterprises (size, experience, monopolistic power, technological or commercial resources, etc.), the latter mirror the capability of MNE hierarchies vis-à-vis external markets to capture the transactional benefits (or lessen the transactional costs), arising from the common governance of a network of assets, located in different countries.

Therefore, within ownership advantages we might include not only tangible assets, but also intangibles (such as a firm's experience, technology, or commercial brand), which are one of the cornerstones of the RBV. This theoretical approach argues that firm's resources and capabilities are the primary sources of competitive advantage (Barney 1991; Peteraf 1993). The RBV is compatible with traditional MNE theory. In fact, Dunning (1988) suggests that ownership factors relate to the multinational's ability to compete in foreign markets and that these advantages derive from unique country, industry, and firm specific variables. Thus, ownership advantages are similar conceptually to firm-specific resources, in that they are the unique internal factors that generate competitive advantages (Fladmoe-Lindquist and Tallman 1994).

Penrose (1956) had already offered an explanation for the continued growth of firms through foreign investment, arguing that the opportunity which invites expansion is not exclusively an external one. It is largely determined by the internal resources of the firm: the new areas in which it can successfully set up plants depend on the kind of experience, managerial ability, and technological know-how already existing in the firm. 
Later, the RBV has been applied to the study of more specific issues concerning FDIs. For instance, it has been used to supplement the explanations on the ownership mode based on minimizing transaction costs (supplied by the Internalization Theory), with those linked to the management of firm's know-how, and not only to the exploitation, but also to the development and display of its capabilities (Madhok 1997). Additionally, the model has been used to justify the firm's degree of commitment in a specific country (Trevino and Grosse 2002).

Ownership advantages may not only condition the FDI decision, but also the choice of the investment mode. First, they may help firms to go beyond the establishment of a representative office, choosing a more advanced mode (joint venture or wholly-owned-subsidiary).

Furthermore, if a firm possesses all the resources and capabilities required to acquire a competitive advantage in a foreign market, it may not even need the contribution of a partner in order to enter such market, and thus decide on a fully-owned subsidiary.

Within this theoretical framework, we are going to propose various hypotheses regarding the influence of various firm-specific factors on the FDI mode in China.

One of the most influential ownership advantages is firm size. Given the fixed costs and risks involved, the propensity to invest abroad is likely to increase in larger firms (Horst 1972). Besides, such larger size implies a higher availability of tangible assets for investment, mainly of a financial nature. This is the reason why many empirical studies have supported that firm size positively correlates with the degree of commitment regarding the entry mode (Stopford and Wells 1972; Yu 1990; Agarwal and Ramaswami 1992; Osborne 1996; Campa and Guillén 1999; Rialp, Axinn and Thach 2002; Trevino and Grosse 2002). This leads us to propose the following hypothesis:

Hypothesis 1. Firm size will be positively associated with the probability of choosing FDI entry modes in China that involve a higher level of resource commitment. 
A second potential ownership advantage may result from firm performance, which traditionally has been considered as a dependent variable (analysis of entry mode and its impact on performance). However, Trevino and Grosse (2002) used it as an independent variable, considering that it was one way to approach the financial resources and other tangible assets possessed by a firm. These authors supported that profitability had a positive influence on firm's degree of commitment. Extending the RBV to the international arena, they suggested that profitability may be interpreted as an ex post fact measure of sustained competitive advantage; that is, the firm must have been competitive to generate profits, and the greater the profitability, the greater its competitive advantage. Another interpretation views profits as a measure of the wealth of the firm; a firm with more accumulated profits will be better able to support overseas expansion through FDI. This leads us to another hypothesis:

Hypothesis 2. Firm performance will be positively associated with the probability of choosing FDI entry modes in China that involve a higher level of resource commitment.

Another influential ownership advantage is firm's international experience. Eriksson, Johanson, Majkgard and Sharma (1997) pointed out that experience-based knowledge is a prominent factor in the internationalization process, according to the Uppsala Model (Johanson and Wiedersheim-Paul 1975; Johanson and Vahlne 1977, 1990). This approach underlines that, as firms progressively gain experience, they carry out more committed strategies.

Welch and Luostarinen (1988) argue that if the firm has already been involved in FDIs in several countries, such firm will have accumulated capabilities and know-how concerning that entry mode, which may be used in other destinations, and even allow the firm to bypass intermediate stages. Those firms with higher investment abroad also possess a higher level of accumulated distinctive competencies, which allow them to overcome what Zaheer (1995) has called "the liability of foreignness", i.e. the additional costs incurred by firms operating in foreign markets, which would not be incurred by a local firm. Thus, Contractor and Kundu 
(1998) and Randoy and Dibrell (2002) found a positive correlation between the scope of a firm's international operations (number of FDIs in different countries) and its degree of investment commitment.

This line of thought is especially interesting for FDIs of Spanish firms in China. Previous FDI experience may help them to reduce the difficulties deriving from entering a country which, albeit culturally distant, offers important location advantages (Durán et al 1995). All these arguments also apply to the choice of a specific FDI mode. It might be expected that Spanish firms which have already had some previous experience with advanced FDI modes, may find it easier to use such entry modes in China. Therefore, our next hypothesis is:

Hypothesis 3. Firm's international experience will be positively associated with the probability of choosing FDI entry modes in China that involve a higher level of resource commitment.

\section{Industry-specific factors}

Internalization Theory stresses the importance of transaction costs when explaining the competitive advantage that MNCs enjoy compared to host country firms (Buckley and Casson 1976; Rugman 1981; Anderson and Gatignon 1986; Hill and Kim 1988). This theory suggests that high ownership is more likely when the firm possesses products and processes with high proprietary content or valuable brand names or other intangible assets (e.g. tacit knowledge, marketing skills, etc.) that may suffer from potential free-riding problems. These assets are difficult to transfer in an imperfect market. The high transaction costs of transferring proprietary assets incurred by companies lead them to internalize markets.

If the source of a firm's competitive advantage is a technological know-how, a transaction in the market implies costs (specifying the agreement conditions, the likelihood of disclosing key 
knowledge, the difficulty to codify such knowledge, etc.) which may constitute a clear incentive for FDI (Teece 1986). Such entry mode proves more efficient when transferring tacit or non-codifiable knowledge enjoying little legal protection (Hennart 1989).

Intangible assets make it difficult to articulate and transfer knowledge by means of an agreement (and therefore, there is always the danger that the local agent may not know how to implement it suitably). Furthermore, the level of firm-specific technology influences the ownership structure, since firms with greater technology may also incur higher transaction costs in safeguarding their technology from misappropriation; in other words, a high level of firm-specific technology tends to create contracting hazards because the impact of opportunism. To safeguard specific assets from potential opportunism problems, firms may use high control governance structures (Tahir and Larimo 2002). This line of reasoning is particularly true for entry mode decisions in China, where intellectual property protection is weaker than in other countries (Chen and $\mathrm{Hu} 2002$ ).

Such positive influence of asset specificity and intangibility on firm's degree of commitment with entry mode has been supported by previous research (Lall 1980; Kim and Hwang 1992; Erramilli and Rao 1993; Kogut and Zander 1993; Osborne 1996; Durán and Úbeda 2002; Nakos, Brouthers and Moussetis 2002; Randoy and Dibrell 2002; Rialp et al 2002; or Brouthers and Brouthers 2003). In addition, Kumar (1984) argued that FDI was the dominant mode of operation in those sectors that were characterized by a high level of R\&D intensity or firm-specific technology. In other words, firms operating in sectors with a high technological component may be expected to be more prone to FDI; more specifically, to modes allowing them a more efficient control of all the tasks to be carried out in the host country. In the case of China, empirical evidence is not conclusive. On the one hand, $\mathrm{Hu}$ and Chen (1993) and Chen et al (2002) found no statistical significance for a positive correlation between the foreign partner's ownership percentage in joint ventures and the technological 
intensity of the industry. Chen and $\mathrm{Hu}$ (2002) observed that a wholly-owned subsidiary was more likely than a contractual joint venture when the foreign firm belonged to a hightechnology industry (although they failed to find any statistical significance for the comparison between wholly-owned subsidiaries and equity joint ventures). Nevertheless, as our study attempts to compare the representative office with other, more advanced FDI modes, the relationship may be formulated as a positive one:

Hypothesis 4. The technological intensity of the industry will be positively associated with the probability of choosing FDI entry modes in China that involve a higher level of resource commitment.

\section{RESEARCH METHODOLOGY}

\section{Sample and Data}

In order to create the directory of firms, various different sources were used. First, we contacted the Spanish Economic and Commercial Offices in Beijing and Hong Kong, which provided us information on Spanish firms located there. Additionally, we consulted two databases: the Foreign Companies in China Yearbook 2001 directory (published by the Commercial Intelligence Service), which lists the foreign firms located in China; and the Iberian Balance Analysis System (SABI) database, which offers data on the equity owned by Spanish firms in foreign countries. All these data were supplemented by those offered by the Spanish Development Financing Company (COFIDES), which offers support to Spanish investment in emerging countries; the BARATZ database, which contains news appeared in financial newspapers since 1981; and The Exporter magazine, which since 1997 has been offering updated information on the international activity of Spanish firms. 
The final list consisted of 129 Spanish firms which had carried out a total of 178 FDIs in China (until late 2002). However, as our empirical analysis will be based on firm variables, we decided to make the firm our unit for analysis, which is why our sample is made up of 129 observations.

The data used in the empirical section are from secondary sources, and were obtained from the following: Spanish Economic and Commercial Office in Beijing, SABI database, Duns 50000. Main Spanish Companies. 2002 Edition directory, financial journals (BARATZ database and The Exporter magazine), corporate websites, COFIDES and Official Spanish Chamber of Commerce in Hong Kong. Before the explanatory analyses are presented for the empirical study, a description of the sample is offered.

The first Spanish FDI in China was carried out in 1984, whereas the most recent ones are from 2002, which, as we said before, is the last year considered for our study. Concerning the industrial distribution of the sample, there is a clear predominance of manufacturing industries (95 cases). Within this category, the most frequent sectors are food products and beverages (17 firms), machinery and equipment (17 firms), and chemical products (12 firms). The remaining 34 firms can be classified as follows: 12 are wholesalers, whereas 22 are involved in miscellaneous activities (business services being the most frequent -7 firms-).

Regarding FDI modes, 47 firms only possess a representative office, which means that the remaining 82 firms have chosen strategies that imply a higher resource commitment. Among the latter, there is a clear predominance of shared ownership (65 firms), and there are only 17 firms with wholly-owned subsidiaries.

\section{Dependent Variable}


Entry mode. In line with most of the research on entry mode choice, our dependent variable is a categorical one (Kogut and Singh 1988; Agarwal and Ramaswami 1992; Kogut and Zander 1993; Contractor and Kundu 1998; Pan and Tse 2000; Luo 2001; etc.). Given the characteristics of the investing modes that can be used in China, we shaped a qualitative variable with three categories, depending on the most committed type of FDI carried out by the firm: (1) only a representative office; (2) joint venture; and 3) wholly-owned subsidiary. We considered as wholly-owned subsidiary that entailing the ownership of $95 \%$ or more of the subsidiary's equity (Hennart and Larimo 1998; Brouthers 2002).Thus, the order of these categories indicates a growing level of resource commitment.

\section{Independent Variables}

Firm size. We used firm turnover as a measure of firm size (Campa and Guillén 1999; Tahir and Larimo 2002). In order to reduce the effect of outliers, we used a logarithmic transformation of this variable. We did not consider the variable 'number of employees' because our sample includes a wide variety of sectors and the labour intensity of firms varies greatly among them.

Firm performance. Studies on entry mode which incorporate this variable have resorted to objective measurements (Pan, Li and Tse 1999; Trevino and Grosse 2002) or subjective ones (Brouthers 2002; Nakos et al 2002), both financial (sales growth, profitability, etc.) and nonfinancial ones (market share, reputation, etc.). Because of the secondary nature of our data, we used objective measurements. In addition, since our purpose was to analyze how the availability of tangible resources influenced the level of investment commitment, we used financial measurements. More specifically, we considered one of the most frequent performance measures in international business research: the return on assets (ROA). The 
average of the last three years available was calculated, in order to eliminate the influence of yearly fluctuations.

International experience. This variable was measured by the number of FDIs the firm had carried out in other countries (Tahir and Larimo 2002; Randoy and Dibrell 2002). We considered previous experience with FDI modes involving a high level of resource commitment (joint ventures or wholly-owned subsidiaries) in countries other than China. It must be emphasized that another way of measuring such overall foreign experience might be the number of years elapsed since the first international transaction carried out by the firm (Erramilli 1991). However, this information was not available in our database.

Industry technological intensity. We classified the line of businesses of foreign investment companies into various technology levels (Dunning 1979; Lee 1983; Hu and Chen 1993; Tahir and Larimo 2002; Chen and Hu 2002; Chen et al 2002). We used the OECD proposal (2001) which, based on the International Standard Industrial Classification (ISIC - revision 3) establishes four categories in manufacturing sectors and two categories in service sectors. Thus, we classified the sectors in our sample into two categories: (0) sectors with a low level of technology and know-how (including low/medium- and low-technology manufacturing sectors, and also services not based on know-how as defined by the original OECD classification); (1) sectors with a high level of technology and know-how (i.e. high- and medium/high-technology manufacturing sectors, and knowledge-based services).

\section{Control Variables}


FDI in Hong Kong. As from July 1, 1997, Hong Kong ceased to be a British colony and became a special administrative region within the People's Republic of China, although it remained as a separate customs territory. Thus, we did not consider investment in Hong Kong in our sample. However, historically, and due to the social, political and economic situation in China, Hong Kong has been the gate into the Chinese market (thanks to its distribution, financial, and management services). Therefore, although the increasing liberalization of China, and especially its accession to the World Trade Organization (WTO) in 2001, is reducing the need for a Hong Kong partner as a way to enter the Chinese market, we still wished to verify if possessing any FDI in Hong Kong may have conditioned the firm's level of commitment in China. Therefore, we used a dummy variable: (0) firm without FDI in Hong Kong; (1) firm with FDI in Hong Kong.

Industry with restrictions to FDI in China. Given that the consequences of China's accession to the WTO have not been fully implemented yet, the regulations which applied to the firms in our sample were the 1995 Interim Regulations on FDI Directions and the 1997 Industrial Catalogue Guiding Foreign Investment which classify the industries into four basic categories: encouraged foreign investment (receiving preferential treatment, both regarding taxes and authorization; these comprise infrastructures, high technology, export industries, recycling industries or those protecting the environment, and also firms using labour and resources from central and western regions); restricted foreign investment (where foreign participation is limited to a maximum of 50\%, which include services trade, activities developed by local firms with owned technology catering for local demand, and rare and precious materials prospection); prohibited foreign investment (which comprise any activities which may affect national security or public order -such as gaming-, polluting activities and Chinese handicraft manufacturing -such as porcellain-); and permitted foreign investment (including all other 
industries, which are completely deregulated, where there is no limit to foreign investment, but there is no incentive under the shape of tax benefits).

Although we removed from our sample some sectors in which there are hindrances to foreign investment (such as the banking sector), the sample still contains other sectors where, for instance, there is the obligation to share the ownership of the subsidiary, which influences the degree of ownership and control entailed by the mode of entry. Therefore, we included another dummy variable: (0) sector with no restrictions on FDI; (1) sector with some kind of restriction.

Project orientation. Project orientation (e.g. export or local market) influences firm behaviour in terms of governance structure and entry mode (Luo 2001). Similarly, the level of resources required could be related to the specific aim of the FDI in China, i.e. the nature of the activity that the firm is going to carry out in China. This is why we used another dummy variable: (0) project orientation was only commercial (e.g. sales or distribution subsidiary); (1) otherwise (e.g. manufacturing subsidiary).

\section{Statistical Model}

As we pointed out above, our dependent variable includes three categories (representative office, joint venture, and wholly-owned subsidiary) that sequentially imply a growing level of resource commitment. For this reason, following Chu and Anderson (1992), we are going to apply an ordered logistic regression model to test the hypotheses (Aulakh and Kotabe 1997; Contractor and Kundu 1998; Pan and Tse 2000).

This regression allows us to shape the dependency of a polytomic ordinal response (dependent variable) on a set of predictors (independent variables). The estimated coefficients reflect how changes in predictors affect the response. In our case, a positive sign indicates that the 
independent variable increases the likelihood of using higher-commitment entry modes, whereas a negative sign implies the opposite relationship. Before applying that logistic regression, we offer the correlation coefficients between independent variables in Table 1 . We calculated the variance inflation factor (VIF) for all independent variables in order to verify the possible existence of multicollinearity. As can be seen, the highest VIF was 1.73 , situated well below 10, the cut-off point recommended by Neter, Wasserman and Kutner (1985). This permits ruling out the presence of multicollinearity in our data.

Table 1.- Descriptive statistics and correlation matrix

\begin{tabular}{|l|c|c|c|c|c|c|c|c|c|}
\hline \multicolumn{1}{|c|}{ Independent variable } & Mean & SD & $\mathbf{1}$ & $\mathbf{2}$ & $\mathbf{3}$ & $\mathbf{4}$ & $\mathbf{5}$ & $\mathbf{6}$ & VIF \\
\hline 1. Firm size (HI) & 7.58 & 0.87 & & & & & & & 1.70 \\
\hline 2. Firm performance (H2) & 7.61 & 10.75 & .01 & & & & & & 1.02 \\
\hline 3. International experience (H3) & 5.46 & 9.38 & .54 & .05 & & & & & 1.73 \\
\hline 4. Industry technological intensity (H4) & 0.46 & 0.50 & .03 & -.10 & -.04 & & & & 1.08 \\
\hline 5. FDI in Hong Kong (control) & 0.12 & 0.32 & .05 & -.04 & -.02 & -.09 & & & 1.13 \\
\hline 6. Industry with restrictions (control) & 0.30 & 0.46 & -.07 & -.03 & .07 & .09 & -.19 & & 1.18 \\
\hline 7. Project orientation (control) & 0.68 & 0.47 & .04 & .07 & .04 & -.04 & .18 & .18 & 1.15 \\
\hline
\end{tabular}

Correlations higher than /.18/ are significant with $\mathrm{p}<.05$; correlations higher than /.50/ are significant with $\mathrm{p}<.01$

\section{RESULTS AND DISCUSSION}

Table 2 shows the results of the ordered logistic regression used to test the hypotheses. 
Table 2.- Ordered logistic regression model

\begin{tabular}{|l|c|}
\hline \multicolumn{1}{|c|}{ Independent variable } & Parameter estimates \\
\hline Firm size $(H 1)$ & $1.622^{* * *}$ \\
\hline Firm performance $(H 2)$ & $0.067^{*}$ \\
\hline International experience $(\mathrm{H} 3)$ & -0.036 \\
\hline Industry technological intensity $(\mathrm{H} 4)$ & -0.070 \\
\hline FDI in Hong Kong (control) & 0.590 \\
\hline Industry with restrictions $($ control) & $-1.701^{* *}$ \\
\hline Project orientation $($ control) & $5.656^{* * *}$ \\
\hline Intercept 1 & $16.168^{* * *}$ \\
\hline Intercept 2 & $20.148^{* * *}$ \\
\hline Chi-Square $=54.575^{* * *}$ & \\
-2 Log likelihood $=79.945$ & \\
\hline $\begin{array}{l}\text { Dependent variable }=1 \text { if Representative Office, } 2 \text { if Joint-Venture, and } 3 \text { if Wholly-Owned } \\
\text { Subsidiary } \\
* * * \mathrm{p}<.01 ; * * \mathrm{p}<.05 ; * \mathrm{P}<.1\end{array}$ \\
\hline
\end{tabular}

First, there is significant statistical evidence for a tangible resource (firm size) which has a positive influence on the choice of FDI modes that involve a higher level of resource commitment; this provides empirical support for Hypothesis 1. As Trevino and Grosse (2002) also noted, our result seems to imply that larger firms are better prepared to absorb the costs resulting from setting up business abroad, thanks to the higher availability of financial resources entailed by firm size.

Regarding Hypothesis 2, it may be thought that more profitable firms are better prepared for higher levels of resource commitment. Again, it must be emphasized that many researchers have usually consider performance as a dependent variable. The result obtained has justified our decision to include it in the model as an independent variable, because there is a positive 
relationship between firm performance and more advanced FDI modes in China. This result is in keeping with that of Trevino and Grosse (2002).

Therefore, as prescribed in Hypotheses 1 and 2, our results suggest that larger firms with greater performance are more likely to choose FDI modes that go beyond opening a representative office, thus assuming a higher level of resource commitment.

Our results do not support hypotheses 3 and 4. Regarding firm's international experience (Hypothesis 3), it may not be so influential in the case of China as in other countries, where cultural differences with Spain are less noticeable. In other words, investment in China may be less conditioned by the general experience acquired by a firm through repeated FDIs in other countries, than by the specific experience regarding China, obtained by having invested more than once. We have not included this kind of experience in our analysis because the vast majority of firms in our sample have only one FDI in China. Anyway, the profit from general international experience could also depend on each firm's absortive capacity, or the set of organizational routines and processes by which firms acquire, assimilate, transform, and exploit knowledge to produce a dynamic organizational capability (Cohen and Levinthal 1990; Zahra and George 2002).

The technological intensity of the industry is not significantly related to a higher resource commitment (Hypothesis 4). As discussed before, such lack of correlation has also been found in other previous empirical studies on foreign investment in China. Hu and Chen (1993) mention, as a possible explanation for this, the lack of innovativeness of the technology contributed by the foreign partner: if the technology is an old one, there is a higher likelihood that the mode of entry should not entail full ownership, whereas wholly-owned subsidiaries will be necessary to ensure a higher control upon more modern technologies (Anderson and Gatignon 1986). Chen et al (2002) attribute the lack of significance to two possible factors: that the specific ownership advantage of the foreign firm is not based on the intangible nature 
of its assets, or that the technological intensity is not so influential in FDI processes in developing countries, such as China.

Regarding control variables, two of them turned out to be significant. More precisely, we observed that the level of resource commitment is higher when the aim of the investing company is not only commercial, but also to carry out other activities in China such as manufacturing. In addition, resource commitment is moderated by the restrictions to foreign investors in the industry.

\section{CONCLUSIONS}

Building on traditional theories of FDI and the RBV, this study has made it possible to highlight several firm- and industry-specific factors which may influence the choice of FDI modes in China that go beyond the representative office. The results show that firm size, firm performance and investments in manufacturing facilities are positively related to entry modes that involve a higher level of resource commitment, although restrictions to foreign investment in the industry affect these relationships.

An initial contribution of this paper is the use of performance as an independent variable which may determine the FDI mode. Traditionally, such variable has been considered a dependent one in studies on entry modes, although with a different purpose: to analyze the influence of the various entry modes on firm's performance. The inclusion of representative offices is another of the contributions, for previous research only considered the two most committed FDI entry modes in China (joint ventures and wholly-owned subsidiaries). It is precisely the representative office that firms resort to when they start their FDI process in China. Another contribution of this paper is the sample of firms coming from Spain. Although over the last years the number of Spanish firms doing business in China has increased considerably, 
their weight is still smaller than those coming from other countries which have so far appeared in FDI research. Furthermore, our study is the first analyzing the choice among FDI entry modes in China by Spanish firms.

In spite of all this, our paper has some limitations, mainly due to the use of secondary data. Thus, this study might be enlarged by including other potential factors influencing the investment decision, such as the firm's international competitive strategy or the degree of diversification resulting from its entry into China. In addition, it might also be interesting to analyze the influence of various FDI modes on firm performance in China, depending on whether the choice fits or not the theoretical models. Such limitations could be overcome by future research collecting primary data through surveys of Spanish firms doing business in China.

\section{REFERENCES}

Agarwal, S., and S.N. Ramaswami (1992), “Choice of Foreign Market Entry Mode: Impact of Ownership, Location and Internalization Factors”, Journal of International Business Studies, 23 (1), 1-27. Anderson, E., and H. Gatignon (1986), "Modes of Foreign Entry: A Transaction Cost Analysis and Propositions", Journal of International Business Studies, 17 (3), 1-26.

Aulakh, P.S., and M. Kotabe (1997), “Antecedents and Performance Implications of Channel Integration in Foreign Markets”, Journal of International Business Studies, 28 (1), 145-175.

Barney, J.B. (1991), "Firm Resources and Sustained Competitive Advantage", Journal of Management, 17 (1), 99-120.

Brouthers, K.D. (2002), "Institutional, Cultural and Transaction Cost Influences on Entry Mode Choice and Performance”, Journal of International Business Studies, 33 (2), 203-221.

Brouthers, K.D., and L.E. Brouthers (2003), "Why Service and Manufacturing Entry Mode Choices Differ: The Influence of Transaction Cost Factors, Risk and Trust”, Journal of Management Studies, 40 (5), 11791204. 
Buckley, P.J., and M. Casson (1976), The Future of the Multinational Enterprise, London: The MacMillan Press.

Campa, J.M., and M.F. Guillén (1999), “The Internalization of Exports: Firm- and Location-Specific Factors in a Middle-Income Country”, Management Science, 45 (11), 1463-1478.

Chadee, D.D. (2002), “Foreign Ownership Structure of Service Equity Joint Ventures in China”, International Journal of Service Industry Management, 13 (2), 181-201.

Chen, H., and M.Y. Hu (2002), “An Analysis of Entry Mode and its Impact on Performance”, International Business Review, 11 (2), 193-210.

Chen, H., M.Y., Hu, and P.S. Hu (2002), “Ownership Strategy of Multinationals from ASEAN: The Case of their Investment in Sino-Foreign Joint Ventures”, Management International Review, 42 (3), 309-326.

China FDI (2003), “Statistics on FDI by Countries. Regions for 2002/2001/2000. FDI Annual Reports", [www document], China FDI-Authoritative Site on Foreign Direct Investment in China, http://www.chinafdi.org.cn

Chu, W., and E.M. Anderson (1992), “Capturing Ordinal Properties of Categorical Dependent Variables: A Review with Application to Modes of Foreign Entry”, International Journal of Research in Marketing, 9 (2), 149-160.

Cohen, W.M., and D.A. Levinthal (1990), “Absorptive Capacity: A New Perspective on Learning and Innovation", Administrative Science Quarterly, 35 (1), 128-152.

Contractor, F.J., S.K. Kundu (1998), "Modal Choice in a World of Alliances: Analyzing Organizational Forms in the International Hotel Sector”, Journal of International Business Studies, 29 (2), 325-358.

Dunning, J.H. (1979), “Explaining Changing Patterns of International Production: In Defence of the Eclectic Theory", Oxford Bulletin of Economics and Statistics, 41 (4), 269-295.

Dunning, J.H. (1981), International Production and the Multinational Enterprise, George Allen \& Unwin: London.

Dunning, J.H. (1988), “The Eclectic Paradigm of International Production: A Restatement and some Possible Extensions”, Journal of International Business Studies, 19 (1), 1-32.

Durán, J.J., and F. Úbeda (2002), “The Economic Capital and the Multinationalisation of Spanish Export Firms. An Integration of Resources Based Approach into the Eclectic Paradigm”, Proceedings of the 28th Annual Conference of European International Business Academy (EIBA), Athens (Greece). 
Durán, J.J., L. Jun, and F. Úbeda (1995), “The International Experience and Intention to Invest in China by Spanish Firms: A Gradualist Approach”, Proceedings of the 21st Annual Conference of European International Business Academy (EIBA), Urbino (Italy).

Eriksson, K., J. Johanson, A. Majkgard, and D.D. Sharma (1997), "Experiential Knowledge and Cost in the Internationalization Process", Journal of International Business Studies, 28 (2), 337-360.

Erramilli, M.K. (1991), “The Experience Factor in Foreign Market Behavior of Service Firms”, Journal of International Business Studies, 22 (3), 479-501.

Erramilli, M.K., and C.P. Rao (1993), “Service Firms International Entry-Mode Choice: A Modified Transaction-Cost Analysis Approach”, Journal of Marketing, 57 (3), 19-38.

Fladmoe-Lindquist, K., and S. Tallman (1994), "Resource-Based Strategy and Competitive Advantage among Multinationals", in Advances in Strategic Management (vol. 10, part A), P. Shrivastava, A. Huff and J. Dutton (Eds.), 45-72, Jai Press Inc.

Guillén, M.F. (2003), “Experience, Imitation, and the Sequence of Foreign Entry: Wholly Owned and JointVenture Manufacturing by South Korean Firms and Business Groups in China, 1987-1995”, Journal of International Business Studies, 34 (2), 185-198.

Hennart, J.F. (1989), “Can the 'New Forms Of Investment' Substitute for the 'Old Forms'?: A Transaction Costs Perspective”, Journal of International Business Studies, 20 (2), 211-234.

Hennart, J.F., and J. Larimo (1998), “The Impact of Culture on the Strategy of Multinational Enterprises: Does National Origin Affect Ownership Decisions?”, Journal of International Business Studies, 29 (3), 515 538.

Hill, C.W., and W.C. Kim (1988), "Searching for a Dynamic Theory of the Multinational Enterprise: A Transaction Cost Model”, Strategic Management Journal, 9 (special issue), 93-104.

Horst, T. (1972), "Firm and Industry Determinants of the Decision to Invest Abroad: An Empirical Study", The Review of Economics and Statistics, LIV (3), 258-266.

Hu, M.Y., and H. Chen (1993), "Foreign Ownership in Chinese Joint Ventures: A Transaction Cost Analysis", Journal of Business Research, 26 (fall). 149-160.

Hymer, S.H. (1976), The International Operations of National Firms: A Study of Direct Foreign Investment, Cambridge, MA: The MIT Press. 
Johanson, J., and J.E. Vahlne (1977), “The Internationalization Process of the Firm. A Model of Knowledge Development and Increasing Foreign Market Commitments”, Journal of International Business Studies, $8(1), 23-32$.

Johanson, J., and J.E. Vahlne (1990), “The Mechanism of Internationalization”, International Marketing Review, 7 (4), 11-24.

Johanson, J., and F. Wiedersheim-Paul (1975), "The Internationalization of The Firm. Four Swedish Cases", Journal of Management Studies, (October), 305-322.

Kim, W.C., and P. Hwang (1992), “Global Strategy and Multinationals’ Entry Mode Choice”, Journal of International Business Studies, 23 (1), 29-53.

Kindleberger, C.P. (1969), American Business Abroad: Six Lectures on Direct Investment, New Haven, CO: Yale University Press.

Kogut, B., and H. Singh (1988), "The Effect of National Culture on the Choice of Entry Mode”, Journal of International Business Studies, 19 (3), 411-432.

Kogut, B., and U. Zander (1993), "Knowledge of the Firm and the Evolutionary Theory of the Multinational Corporation”, Journal of International Business Studies, 24 (4), 625-645.

Kumar, N. (1984), "Growth, Acquisition and Investment. An Analysis of the Growth of Industrial Firms and their Overseas Activities", Cambridge: Cambridge University Press.

Lall, S. (1980), “Monopolistic Advantages and Foreign Involvement by U.S. Manufacturing Industry”, Oxford Economic Papers, 32 (1), 102-122.

Lee, C.H. (1983), "International Production of the United States and Japan in Korean Manufacturing Industries: A Comparative Study”, Weltwirtschaftliches Archiv, 119 (4), 744-753.

Luo, Y. (2001), “Determinants of Entry in an Emerging Economy: A Multilevel Approach”, Journal of Management Studies, 38 (3), 443-472.

Madhok, A. (1997), "Cost, Value and Foreign Market Entry Mode: The Transaction and the Firm”, Strategic Management Journal, 18 (1), 39-61.

Nakos, G., K.D. Brouthers, and R. Moussetis (2002), “Greek and Dutch SMEs Entry Mode Choice and Performance: A Transaction Cost Perspective", Proceedings of the 28th Annual Conference of European International Business Academy (EIBA), Athens (Greece). 
Neter, J., W. Wasserman, and M.H. Kutner (1985), Applied Linear Statistical Models: Regression, Analysis of Variance and Experimental Designs, 2nd ed., Homewood: Irwin.

OECD (2001), Science, Technology and Industry Scorecard 2001, Paris: OECD.

Osborne, K. (1996), "The Channel Integration Decision for Small-to Medium-Sized Manufacturing Exporters", International Small Business Journal, 14 (3), 40-56.

Pan, Y. (1996), "Influences on Foreign Equity Ownership Level in Joint Ventures in China", Journal of International Business Studies, 27 (1), 1-26.

Pan, Y., and D.K. Tse (2000), “The Hierarchical Model of Market Entry Modes”, Journal of International Business Studies, 31 (4), 535-554.

Pan, Y., S. Li, and D.K. Tse (1999), "The Impact of Order and Mode of Market Entry on Profitability and Market Share”, Journal of International Business Studies, 30 (1), 81-103.

Peng, M.W., Y. Lu, O. Shenkar, and D.Y.L. Wang (2001), “Treasures in the China House. A Review of Management and Organizational Research on Greater China”, Journal of Business Research, 52 (2), 95 110.

Penrose, E.T. (1956), "Foreign Investment and The Growth of the Firm", The Economic Journal, (June), 220235.

Peteraf, M.A. (1993), “The Cornerstone of Competitive Advantage: A Resource-Based View”, Strategic Management Journal, 14 (3), 179-191.

Randoy, T., and C.C. Dibrell (2002), "How and Why Norwegian MNCs Commit Resources Abroad: Beyond Choice of Entry Mode”, Management International Review, 42 (2), 119-140.

Rialp, A., C. Axinn, and S. Thach (2002), "Exploring Channel Internalization among Spanish Exporters", International Marketing Review, 19 (2), 133-155.

Rugman, A.M. (1981), Inside the Multinationals. The Economics of Internal Markets, New York: Columbia University Press.

Stopford, J.M., and L.T. Wells (1972), Managing the Multinational Enterprise. Organization of the Firm and Ownership of the Subsidiaries, New York: Basic Books, Inc., Publishers.

Tahir, R., and J. Larimo (2002), "Determinants of Ownership Choices of Finnish Firms in Asian Countries", Proceedings of the 28th Annual Conference of European International Business Academy (EIBA), Athens (Greece). 
Teece, D.J. (1986), “Transactions Cost Economics and the Multinational Enterprise. An Assessment”, Journal of Economic Behavior and Organization, 7, 21-45.

Trevino, L.J., and R. Grosse (2002), “An Analysis of Firm-Specific Resources and Foreign Direct Investment in the United States", International Business Review, 11 (4), 431-452.

Tse, D.K., Y. Pan, and K.Y. Au (1997), "How MNCs Choose Entry Modes and Form Alliances: The China Experience”, Journal of International Business Studies, 28 (4), 779-805.

UNCTAD (2005), World Investment Report 2005. Transnational Corporations and the Internationalization of R\&D, New York and Geneva: United Nations.

Welch, L.S., and R. Luostarinen (1988), "Internationalization: Evolution of a Concept”, Journal of General Management, 14 (2), 34-55.

Yu, C.M.J. (1990), “The Experience Effect and Foreign Direct Investment”, Weltwirtschaftliches Archiv, 126 (4), 561-580.

Zaheer, S. (1995), “Overcoming the Liability of Foreignness”, Academy of Management Journal, 38 (2), 341 363.

Zahra, S.A., and G. George (2002), “Absorptive Capacity: A Review, Reconceptualization, and Extension”, Academy of Management Review, 27 (2), 185-203. 